\title{
The Research of Factors Affecting the Quality of Audit Activities: Empirical Evidence in Vietnam
}

\author{
Phan Thanh Hai ${ }^{1}$ \\ ${ }^{1}$ Duy Tan University, Da Nang City, Vietnam \\ Correspondence: Phan Thanh Hai, Ph.D, Dean, Faculty of Accounting, Duy Tan University, Da Nang City, \\ Vietnam. E-mail: phanthanhhai@duytan.edu.vn or phanthanhhai1281@gmail.com
}

Received: December 18, 2015

Accepted: January 19, $2016 \quad$ Online Published: February 25, 2016

doi:10.5539/ijbm.v11n3p83

URL: http://dx.doi.org/10.5539/ijbm.v11n3p83

\begin{abstract}
The purpose of this study is to determine the factors that affect the quality of auditing activities in Vietnam. Through the method of qualitative research and quantitative based user auditing reliability Cronbach's Alpha, testing factors explored (EFA) and the regression analysis, the results of the study showed much weaker influences with different levels of influence on the quality of independent auditing activities. Which elements of the organizational structure, scope of services provided are the factors that have the greatest impact on the quality of the audit. Besides the elements of the cost and staff capacity, ownership of enterprises audit, quality control work inside, quality control work outside also have implications significantly to the quality of audit activities in Vietnam.
\end{abstract}

Keywords: factors, audit activities quality, Vietnam, quantitative research

\section{Introduction}

Until now, there have been many studies published on the independent audit and the factors affecting the quality of audit activities. Among them can be raised in many research works of different authors related to the quality of audit activities and the factors affecting the quality of the audit, such as studies of DeAngelo (1981), Francis and Al (1987, 1988, 1999) ... on audit fees; Burton's study (1986), Grimlund (1990), Lennox (1999), Shu (2000), Chia-Chi Lee (2008) ... on the audit firm size; Bonner's research (1990), Malone and Roberts (1996), Wooten (2003), Chen (2009) ... on matters related to the auditors, the study by Tran TG Tan (2009), K. Tran Lam (2011), Ha Ha TN (2011) .. on control audit quality from inside and outside corporate auditor;

However, in recently, no works of any published by author study factors affecting the quality of auditing in Vietnam. This is also the reason for the author to undertake research on this topic and introduce detailed the contents of the study in the next section of the article.

\section{Literature Review}

\subsection{The Quality of Audit Activities}

The quality of audit activities is the subject of research by many scientists until now and therefore there are many different views regarding audit quality. Can typical views of GAO (2003, p. 13), the quality audits are conformity with Generally Accepted Auditing Standards (GAAS) to provide reasonable assurance that the financial statements the audited and related disclosures are: (1) presented in accordance with Generally Accepted Accounting Principles (GAAP) and (2) are not contained the key issues related to false errors or fraud. Other studies also point to this as studies of Tie (1999); Krishnan and Schauer (2001). There are also a number of researchers to follow the opposite direction it was introduced the concept of the poverty of the quality of audit by identifying the disadvantage results from audits (Peecher and Piercey, 2008). In addition to the above-mentioned there are also numerous other studies mentioned audit quality such as DeAngelo (1981); Watts and Zimmerman (1983); Lee et al. (1983); Aldhizer et al. (1995); McConnell and Banks, (1998); Krishnan and Schauer (2001); Wallace (1987); Beatty (1989); Krinsky and Rotenberg (1989); Davidson and Neu (1993) and some other authors.

\subsection{The Factors that Affect Audit Quality}

Recently, there are plenty of research on the quality and the factors that affect audit quality. However in view of 
the author can be divided into two main groups.

The First, the individual study of each factor affects audit quality. This research direction is gaining the attention of many authors. Typical of these are the following factors.

\subsubsection{The Size of Auditing Firms}

Accordingly to some authors showed that the larger audit firm size tend to provide better audit services (Burton, 1986; Grimlund, 1990). Research by DeAngelo (1981) also concluded the audit firms, which has large scale is often evaluated higher quality in the market than a small company. Also Lennox (1999) and Shu (2000) suggested that the auditing company with the large of scale and resources may reduce the possibility of the litigation and ensure the maintenance of quality of audit services at a high level.

The research of author Chia-Chi Lee (2008) also pointed out that the size of the audit firm have significantly affect to the performance, especially in the relationship between the type of comparison between the international audit Firms, large-size audit firms, medium-size audit firms ; however, these affection is trivial in comparison relationship between, medium-size audit Firms and small-size audit firms.

Thus, studies of the authors clearly explain the relationship has influenced the scale of auditing firms to audit quality.

\subsubsection{Non-Audit Services Provided by Audit Firms}

There are multiple authors mentioned this factors. Basically results show that this is a relationship factor inversely to the quality and efficiency of the audit.

Experimental research via surveys 1,500 auditors of Lindberg and Beck (2002) after the Enron showed that most of the auditors agree that the client service would harm the independence of the auditor. In terms of professional ethics once independence diminished the quality audit also decline. The study of Sisumic (1984), Beck et al (1988) also pointed out that the provision of non-audit services can increase economic relationships between auditors and clients.

This relationship is increasingly strict then the result in audit quality would be affected in a negative way. The previous study of Mautz and Sharaf (1961) have mentioned the service management consulting and tax advisory firm providing audit will affect the independence of the audit firm. Also, according to Simunic (1984), the economic relationship between the customer and the audit firm may increase due to a combination of providing non-audit services and audit services. This reason has made auditing firms tend to make concessions to customers when there is disagreement in the process of performing the audit aims to keep customers.

\subsubsection{Issues Related to Auditors and Manager of Audit Firm}

The knowledge and capabilities of the auditor is the factors that related and directly influence the quality of the audit quality. The results of many studies showed specialized knowledge of every detail accumulated through customer before, assigned tasks and professional experience in occupations related to the evaluation of higher quality of audit Users (Bonner, 1990) and required for professional development audit (Frederick \& Libby, 1986; Bonner \& Lewis, 1990). Other studies also indicate the knowledge and capabilities of the auditor plays a very important role in the discovery of errors in the audit process (Owhoso et al., 2002), meant so decided the results of the implementation of the analytical procedures (Wright, 1997) or assess the components of audit risk (Low, 2004; Hammersley, 2006; Maroney \& Simnett, 2009). Also study of O'Keefe et al (1994) also pointed out the close relationship between knowledge and capabilities with compliance with generally accepted Auditing Principles (GAAPs).

Research by Chen et al (2009) noted a positive relationship between the professional skepticism and audits. Specifically, auditors perform a higher level of professional skepticism or perform additional procedures when abnormalities (Shaub \& Lawrence, 1996), or notice is more likely to detect fraud, less confidence in customers, and is likely to invest in a high level for the efforts in the audit process.

The related between the personality of the auditors and the audit quality is also interested research of Kelly and Margheim (1990), Raghunathan (1991) show that audit quality is not always be achieved through analyzing the behavior of auditors in auditing the same company. If auditors tend to overlook the audit procedures, the audit quality certainly will be affected in a negative direction. These authors identify that the practices that reduce audit quality is defined as the act of auditors that reduce the effectiveness and relevance of the evidence testing collect payment.

The study of Malone and go after as Roberts (1996) about the relationship between the behavioral impact of reduced audit quality and time pressure on the assigned tasks specified feel pressure each auditor on the 
procedures for management and audit quality review of the company they are working with inversely proportional relationship with practices that reduce audit quality. Also Wooten (2003) showed that the control of the owner of stake and audit managers, the experiences of the auditors on trades and business activities of our customers, the professionalism of auditors, perseverance and professional skepticism that affect audit quality.

\subsubsection{Audit Fees}

Up to now, there are several researches mention the impact of audit fees to audit quality. Although there are many different views, but basically the idea that the reduction of audit fees often leads to reduced audit quality, many researchers agreed. Explanation for this is that the lower of fees may affect the time and cost to prepare for the audit will be lowered thereby causing pressure and difficulty for auditors in the release out of material misstatement.

The first is research by De Angelo (1981) with the introduction of the model audit fees and expenses. This model has helped to specify the relationship between the cost of the audit and the relationship with the customer. Specifically, it is the audit firm tend to fix the audit fees in the first year under the actual cost that the company spent to obtain additional profit in the future from the implementation of this contract. This also creates economic relationship with customers thereby undermine the independence of auditors and lead to reduced audit quality.

After that, the research of Francis and Simon (1987), Simon and Francis (1988), Crasswell and Francis (1999) also provided further evidence that the auditing companies tend to reduce audit fees for the first year for more customers.

\subsubsection{Quality Control from Inside and Outside Audit Firm}

In his research going into the evaluation the fundamental limitations of quality control mechanisms for independent auditing activities in Vietnam in both aspects of quality control from inside and outside audit firms, the author Tran K. Lam (2011) said that: "The independent auditing firms in Vietnam, which have greater scale, lager financial resources as abundant, higher index quality audit and rotation of auditors periodically, consistently achieve better audit quality; lowering the cost of the audit have certain influence on the quality of the audit. Majority of small audit firms lack the resources should not be able to maintain or implement steadily the building systems and defense policy Quality control procedures effectively; the implementation of quality control from the inside of the independent audit firms in Vietnam have not been adequate attention".

Also through his research, the author Ha (2011) has gone further into the assessment of the status of quality control audit of financial statements of entities in the public interest Vietnam in the period from 2008-2010. Research results have shown the relationship between control external quality audit quality is very necessary and extremely important, especially the audit of financial statements of listed companies, public companies in Vietnam.

Earlier studies of Vu M. Hai (2007), Tran T. G. Tan (2009, 2010) has also said that audit quality control from inside acted extremely important impact on the quality of reports audit and providing information to various audiences use.

\subsubsection{Career Development Strategy and Legal Basis}

Some studies of many authors have pointed out the close relationship between quality audit at the audit enterprise with the trade development strategy by the Government and published professional associations, as well as the War business strategy of audit firms. This proven and shown through many studies (such as Ngo T. Chi và Bui Mai, 2006; Vuong Hue, 2006; Le Phuong, 2006; Tran Anh, 2008). Beside that many studies have shown that the legal basis is one of the factors that have great influence on the quality of independent auditing activities in Vietnam. This is demonstrated through the study of Ha Ha (2007), Ngo Ha (2007), Doan Tien (2009), Nguyen Do (2010). All of these studies have indicated: strategic and legal basis as tight, complete the audit quality as possible.

\subsubsection{Organizational Operation Models and Ownership of the Audit Firm}

On this aspect also had many scientists have given different views on the organizational model audit activities and its impact on the quality of audit. Typical may include research organizations operating models perspective, according to the relationship between the organizations promulgating auditing standards, monitoring audit work with audit firms Vu Duc (2002). Accordingly, whether self-control models, models statutory, independent commission models or state model - advisory council, each models offers a significant influence on the quality of auditing activities mathematics; and different countries depending on several factors to choose and apply 
appropriate models.

Besides, there are also studies on the organization and operation models in terms of subjects conducting audit of Alvin A. Arens (2000). In view of this, the researchers have two organizational models that audit activities are role models through individual (private office audit) and models entities (audit firms with the various forms of ownership). Simultaneously with the study of Alvin A. Arens (2000), the study by Oxera Consulting Ltd (2007) also pointed out the different forms of ownership, it has different effects on the quality and efficiency of audit.

Additionally the study also point to the organizational model audit activities in terms of organization and management of enterprise activities such as research audit of Phan L. T. Long (2009) 3 organization and management models audit of various activities such as models Network, Associations and Alliances, Organisations. Each models shall have a certain influence on the quality of audit activities of the audit firms at different levels.

Second, the research refers to a variety of factors affect the quality of audit.

There are many studies in recent research mentioned in the view that the impact on audit quality include many factors. Typically, some of the following research:

Lin Ling's research and Tepalagul Nopmanee Kong (2010) pointed out that: the factors affecting the quality of the audit focused on a number of factors related to threats to the independence of auditors as : the importance of the customer, non-audit services, the auditor's term, the relationship between customer and staff auditors. Meanwhile according to Robert Knechel et al. (2012) says: tenure of the auditors; market perception of the quality audit; fees for non-audit services; work pressure as well as professional knowledge, ability cynical nature as well as career-related policy and incentive to encourage employees, audit quality; deal with customers ... are the factors that affect to audit quality.

Besides, the study of UK Financial Reporting Council- FRC (2008) show that the factors affecting the quality of the audit included a number of factors such as audit firm's culture, the effectiveness of the audit process, the relevance and usefulness of the report audit was announced, skills and quality of human resources, factors outside the control of the auditors. In each of the above factors affect the FRC has continued in-depth analysis and provide criteria for evaluation. Such as factors related to the culture of the company auditor is satisfied based on several criteria such as creating environments to achieve higher added value in terms of quality, and remuneration policies Bonus and ensure employees can have enough time and resources to solve difficult problems. While factors related to the effectiveness of the audit process in the company is analyzed based on criteria such as design methodologies and audit tools, the implementation of standards of professional ethics and auditing standards, technical support and so on.

Summary, from a review of studies presented above may have the conclusion that, depending on the perspective and the perspective of the authors study the factors that affect audit quality, because audit quality is the invisible product and received concern of many objects.

The views of the author of that article is the quality audits always influenced by many different factors, so on the basis of the theoretical foundation and the research of other authors before; simultaneously combined with in-depth interviews reviews of some experts in the field of audit, finance and accounting in Vietnam, the authors propose a model as follows: 


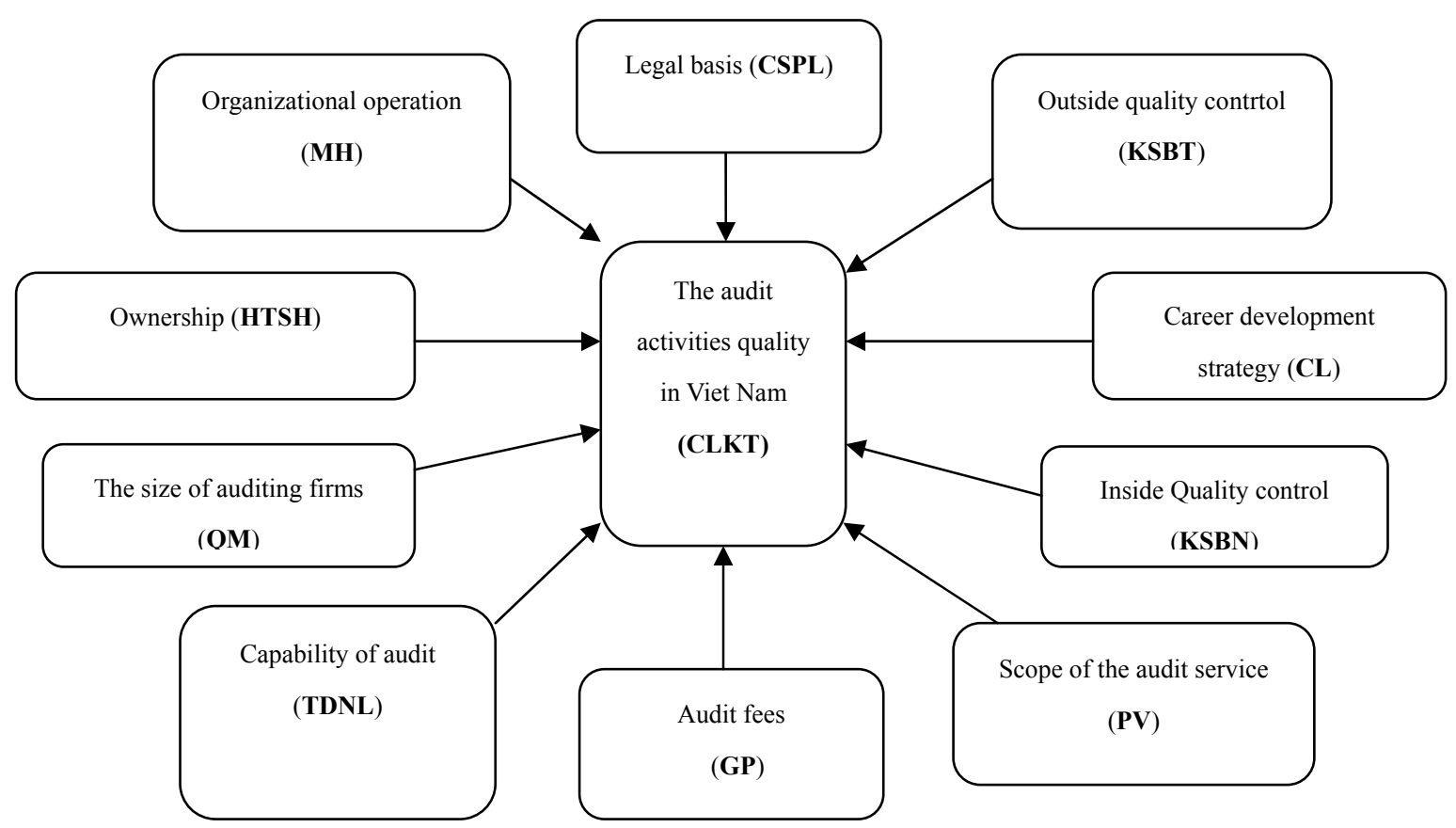

Figure 1. Proposed model of factors affecting the audit activities quality in Viet Nam

\section{Data and Research Methodology}

Data was collected from the survey conducted in the $4^{\text {th }}$ quarter of 2013 and the $1^{\text {st }}, 2^{\text {nd }}$ quarter of 2014 with opinion of the auditors, the managers at the audit firm in all the different cities in Vietnam. Results have 400 peoples (out of a total of more than 1,000 auditors available in Vietnam) participated in this research survey. After the exclusion of invalid survey panels, the total quantity of qualified panels is 387 panels which are sufficient to assure the credibility of data analysis.

To achieve the goals set at the beginning of this article, the author has used a combination of the methods of qualitative research and quantitative research methods including quantitative determination is essential.

Qualitative research methods were conducted through interviewing techniques expert opinion. To obtain feedback on the factors affecting the quality of auditing activities, the author has collected the opinions of various experts groups including managers of the Ministry of Finance, Vietnam Association Certified Public Accountant (VACPA), the general manager, CEO, audit partner of the auditing firms have large scale. On the basis of gathering opinions from experts, authors have drafted a questionnaire survey conducted surveys simultaneously try to check the suitability of content questions, adjust and rearrange the questions thereby forming an official scale to serve the large-scale survey on the audit in most audit firms in all cities and provinces in Vietnam.

Quantitative research methods used by the author through the steps: designing the study sample, collected data from surveys, data analysis by SPSS version 15.0 software. This software is used to summarize and present the basic data regarding the frequency table appear survey variables, statistical description of factors and their impact on the quality of audit activities. In this study, first author used the technique Cronbach's Alpha Test to test the factors in the scale then use techniques Exploratory Factor Analysis (EFA) to reduce the observed variables, renamed variables and modeling shortened; author finally ran regression models through regression analysis techniques in order to conclude a final assessment of the factors that affect the quality of auditing activities in Vietnam.

\section{Result and Discussion}

In this survey, the authors propose a model of 42 variables independent observers (variables) gathered in 10 groups of factors (Factors) and 4 observers for the dependent variable. To test the reliability of the scale model of the original author used the Cronbach's Alpha testing. The result is that all these factors are consistent and do not remove any marginal observations from the model. 
Table 1 . Testing the rating scale by Cronbach's Alpha reliability coefficient (reliability statistics item-total statistics)

\begin{tabular}{|c|c|c|c|c|}
\hline \multicolumn{5}{|c|}{ Rating scale of Factor No.1, Cronbach's Alpha $=0.821$} \\
\hline Items & Scale Mean if Item Deleted & $\begin{array}{l}\text { Scale Variance if Item } \\
\text { Deleted }\end{array}$ & $\begin{array}{l}\text { Corrected Item Total } \\
\text { Correclation }\end{array}$ & $\begin{array}{l}\text { Cronbach's Alpha if } \\
\text { Item Deleted }\end{array}$ \\
\hline MH1 & 13.6460 & 8.338 & .714 & .757 \\
\hline MH2 & 13.5426 & 8.855 & .725 & .761 \\
\hline MH3 & 13.7907 & 8.083 & 686 & .764 \\
\hline MH4 & 14.2145 & 9.169 & .445 & .839 \\
\hline MH5 & 13.9121 & 8.920 & .551 & .805 \\
\hline \multicolumn{5}{|c|}{ Rating scale of Factor No.2, Cronbach's Alpha $=0.891$} \\
\hline HTSH1 & 15.0517 & 11.215 & 662 & .883 \\
\hline HTSH2 & 15.0930 & 10.437 & .743 & .866 \\
\hline HTSH3 & 15.2093 & 9.824 & .761 & .862 \\
\hline HTSH4 & 15.2584 & 10.057 & .782 & .857 \\
\hline HTSH5 & 15.2946 & 9.975 & .733 & .869 \\
\hline \multicolumn{5}{|c|}{ Rating scale of Factor No.3, Cronbach's Alpha $=0.823$} \\
\hline QM1 & 14.88372 & 9.746 & .346 & .861 \\
\hline QM2 & 14.65891 & 7.588 & .756 & .743 \\
\hline QM3 & 14.64599 & 7.494 & .794 & .731 \\
\hline QM4 & 14.55556 & 8.797 & .647 & .781 \\
\hline QM5 & 14.66150 & 8.525 & .576 & 799 \\
\hline \multicolumn{5}{|c|}{ Rating scale of Factor No.4, Cronbach's Alpha $=0.701$} \\
\hline TDNL1 & 13.9793 & 5.994 & .430 & .664 \\
\hline TDNL2 & 13.8941 & 5.245 & .707 & .543 \\
\hline TDNL3 & 13.7933 & 5.693 & .602 & .593 \\
\hline TDNL4 & 13.8475 & 6.383 & .378 & .683 \\
\hline TDNL5 & 13.3953 & 6.711 & .232 & .747 \\
\hline \multicolumn{5}{|c|}{ Rating scale of Factor No.5, Cronbach's Alpha $=0.825$} \\
\hline PL1 & 11.6512 & 4.451 & 685 & .764 \\
\hline PL2 & 11.5943 & 4.387 & .784 & .723 \\
\hline PL3 & 11.5943 & 4.423 & .590 & .811 \\
\hline PL4 & 11.5788 & 4.706 & .564 & .818 \\
\hline \multicolumn{5}{|c|}{ Rating scale of Factor No.6, Cronbach's Alpha $=0.788$} \\
\hline KSBN1 & 11.17571 & 6.171 & .310 & .872 \\
\hline KSBN2 & 10.93540 & 4.563 & .744 & .654 \\
\hline KSBN3 & 11.03618 & 4.356 & .786 & .628 \\
\hline KSBN4 & 10.89922 & 5.593 & 605 & .735 \\
\hline \multicolumn{5}{|c|}{ Rating scale of Factor No.7, Cronbach's Alpha $=0.780$} \\
\hline CL1 & 7.2817 & 2.633 & .510 & .831 \\
\hline CL2 & 7.3411 & 2.635 & .681 & .638 \\
\hline CL3 & 7.3204 & 2.565 & .678 & .637 \\
\hline
\end{tabular}




\begin{tabular}{|c|c|c|c|c|}
\hline \multicolumn{5}{|c|}{ Rating scale of Factor No.8, Cronbach's Alpha $=0.831$} \\
\hline KSBT1 & 11.1550 & 5.100 & .796 & .723 \\
\hline KSBT2 & 11.1214 & 5.190 & .747 & .745 \\
\hline KSBT3 & 11.1318 & 5.788 & .668 & .784 \\
\hline KSBT4 & 11.1731 & 6.164 & .456 & .877 \\
\hline \multicolumn{5}{|c|}{ Rating scale of Factor No.9, Cronbach's Alpha $=0.817$} \\
\hline PV1 & 7.5556 & 2.315 & .655 & .766 \\
\hline PV2 & 7.5788 & 2.467 & .682 & .737 \\
\hline PV3 & 7.6305 & 2.462 & .674 & .744 \\
\hline \multicolumn{5}{|c|}{ Rating scale of Factor No.10, Cronbach's Alpha $=0.838$} \\
\hline GP1 & 10.4031 & 5.257 & .531 & .854 \\
\hline GP2 & 10.3721 & 4.271 & .809 & .728 \\
\hline GP3 & 10.3204 & 4.679 & .699 & .781 \\
\hline GP4 & 10.3695 & 5.140 & .654 & .802 \\
\hline \multicolumn{5}{|c|}{ Rating scale measuring the audit activities quality in VietNam, Cronbach's Alpha $=0.763$} \\
\hline CLKT1 & 10.5788 & 5.006 & .592 & .693 \\
\hline CLKT2 & 10.6098 & 4.928 & .565 & .706 \\
\hline CLKT3 & 10.9302 & 4.889 & .456 & .771 \\
\hline CLKT4 & 10.6408 & 4.557 & .655 & .655 \\
\hline
\end{tabular}

As can be seen in the test result of the rating scale measuring the audit activities quality in Viet Nam, the Cronbach's Alpha $=0.763(>0.6)$, the gross correlation coefificients are approximately or greater than 0.5 (much more than the acceptable level of 0.3 ); hence, the reliability of this rating scale is acceptable.

After the Cronbach's Alpha test, we used the result acquired from the summary of 387 eligible answers and input variables into EFA to take out factors. The result of the selection of Varimax rotation and shortened down to the variable load factor less than 0:55 after the second time running, the results showed: $\mathrm{KMO}=0.849$ with $\mathrm{Sig}=$ 0.000 significance level and extracting 7 factors with the gross $\mathrm{s}$ variance extracted $=72.505 \%$. From the original model with 10 factors that affect the models stripped after testing run EFA remaining seven factors detailed results through the following table.

Table 2. Result of the second exploratory factor analysis with varimax rotation (KMO and Bartlett's test)

\begin{tabular}{lll}
\hline Kaiser-Meyer-Olkin Measure of Sampling Adequacy & & .849 \\
\hline Bartlett's Test of Sphericity & Approx. Chi-Square & 9446.951 \\
& Df & 496 \\
& Sig. & .000 \\
\hline
\end{tabular}

\begin{tabular}{|c|c|c|c|c|c|c|c|c|c|}
\hline \multirow[b]{3}{*}{ Component } & \multicolumn{3}{|c|}{ Initial Eigenvalues } & \multicolumn{3}{|c|}{ Extraction Sums of Squared Loadings } & \multicolumn{3}{|c|}{ Rotation Sums of Squared Loadings } \\
\hline & \multirow[b]{2}{*}{ Total } & \multicolumn{2}{|c|}{$\% \quad$ of } & \multirow[b]{2}{*}{ Total } & \multicolumn{2}{|c|}{$\% \quad$ of } & \multirow[b]{2}{*}{ Total } & \multicolumn{2}{|c|}{$\% \quad$ of } \\
\hline & & Variance & Cumulative $\%$ & & Variance & Cumulative \% & & Variance & Cumulative $\%$ \\
\hline 1 & 10.110 & 31.592 & 31.592 & 10.110 & 31.592 & 31.592 & 5.583 & 17.447 & 17.447 \\
\hline 2 & 4.250 & 13.282 & 44.875 & 4.250 & 13.282 & 44.875 & 4.325 & 13.515 & 30.962 \\
\hline 3 & 2.657 & 8.303 & 53.178 & 2.657 & 8.303 & 53.178 & 3.529 & 11.029 & 41.990 \\
\hline 4 & 2.128 & 6.649 & 59.827 & 2.128 & 6.649 & 59.827 & 2.662 & 8.318 & 50.308 \\
\hline 5 & 1.611 & 5.034 & 64.861 & 1.611 & 5.034 & 64.861 & 2.570 & 8.031 & 58.339 \\
\hline 6 & 1.327 & 4.147 & 69.007 & 1.327 & 4.147 & 69.007 & 2.348 & 7.337 & 65.677 \\
\hline 7 & 1.119 & 3.497 & 72.505 & 1.119 & 3.497 & 72.505 & 2.185 & 6.828 & 72.505 \\
\hline
\end{tabular}




\begin{tabular}{|c|c|c|c|}
\hline 8 & .900 & 2.812 & 75.316 \\
\hline 9 & .774 & 2.420 & 77.736 \\
\hline 10 & .707 & 2.210 & 79.946 \\
\hline 11 & .623 & 1.947 & 81.893 \\
\hline 12 & .590 & 1.845 & 83.738 \\
\hline 13 & .545 & 1.702 & 85.440 \\
\hline 14 & .491 & 1.535 & 86.975 \\
\hline 15 & .417 & 1.304 & 88.279 \\
\hline 16 & .395 & 1.234 & 89.513 \\
\hline 17 & .365 & 1.140 & 90.653 \\
\hline 18 & .347 & 1.083 & 91.736 \\
\hline 19 & .339 & 1.058 & 92.794 \\
\hline 20 & .323 & 1.008 & 93.802 \\
\hline 21 & .305 & .954 & 94.756 \\
\hline 22 & .240 & .750 & 95.505 \\
\hline 23 & .219 & .686 & 96.191 \\
\hline 24 & .206 & .644 & 96.835 \\
\hline 25 & .176 & .551 & 97.386 \\
\hline 26 & .161 & .504 & 97.890 \\
\hline 27 & .146 & .455 & 98.345 \\
\hline 28 & .129 & .404 & 98.749 \\
\hline 29 & .118 & .369 & 99.118 \\
\hline 30 & .103 & .321 & 99.438 \\
\hline 31 & .094 & .292 & 99.731 \\
\hline 32 & .086 & .269 & 100.000 \\
\hline
\end{tabular}

Extraction Method: Principal Component Analysis.

Rotated Component Matrix ${ }^{\mathrm{a}}$

\begin{tabular}{|c|c|c|c|c|c|c|c|}
\hline \multicolumn{8}{|l|}{ Factor } \\
\hline & 1 & 2 & 3 & 4 & 5 & 6 & 7 \\
\hline MH1 & & & .824 & & & & \\
\hline MH2 & & & .783 & & & & \\
\hline MH3 & & & .737 & & & & \\
\hline MH4 & & & .573 & & & & \\
\hline MH5 & & & .710 & & & & \\
\hline HTSH3 & & & & & & .698 & \\
\hline HTSH4 & & & & & & .677 & \\
\hline HTSH5 & & & & & & .645 & \\
\hline QM2 & .716 & & & & & & \\
\hline QM3 & .751 & & & & & & \\
\hline QM4 & .872 & & & & & & \\
\hline TDNL2 & & .800 & & & & & \\
\hline TDNL3 & & .752 & & & & & \\
\hline TDNL4 & & .576 & & & & & \\
\hline PL1 & .826 & & & & & & \\
\hline PL2 & .832 & & & & & & \\
\hline KSBN2 & & & & .847 & & & \\
\hline KSBN3 & & & & .828 & & & \\
\hline KSBN4 & & & & .768 & & & \\
\hline CL1 & .672 & & & & & & \\
\hline CL2 & .741 & & & & & & \\
\hline
\end{tabular}




\begin{tabular}{llll}
\hline CL3 & .680 & & .815 \\
KSBT1 & & .783 & .843 \\
KSBT2 & & & .631 \\
KSBT3 & & .757 \\
PV1 & & & .737 \\
PV2 & & & \\
PV3 & .682 & \\
GP1 & .857 & & \\
GP2 & .797 & & \\
GP3 & .757 & & \\
GP4 & & \\
\hline
\end{tabular}

Extraction Method: Principal Component Analysis.

Rotation Method: Varimax with Kaiser Normalization.

a Rotation converged in 7 iterations.

As can be seen, 7 factors with the gross variance extracted equal to $72.505 \%$, which mean these 7 factors can explain for $72.505 \%$ of the audit activities quality in Viet Nam, the remaining $27.495 \%$ depends on other factors that are oversaw in this study.

The calibration model comprises of 7 factors that have inpact on the quality of auditing activities in Vietnam, namely: factor no. 1, which is referred to in our study as "Governance of the audit profession" (QUANLYNHANUOC); factor no. 2 called "Contingent capacity and audit fees"; factor no. 3 called "Organizational model audit activities" (MOHINHTOCHUC); factor no. 4 called "Ownership of auditing firms" (HINHTHUCSOHUUDNKT); factor no. 5 called "Quality control from outside" (KSCLBENNGOAI); factor no. 6 called "Quality control inside" (KSCLBENTRONG) and the final factor called "Scope of the audit service provide to client" (PHAMVICCDV).

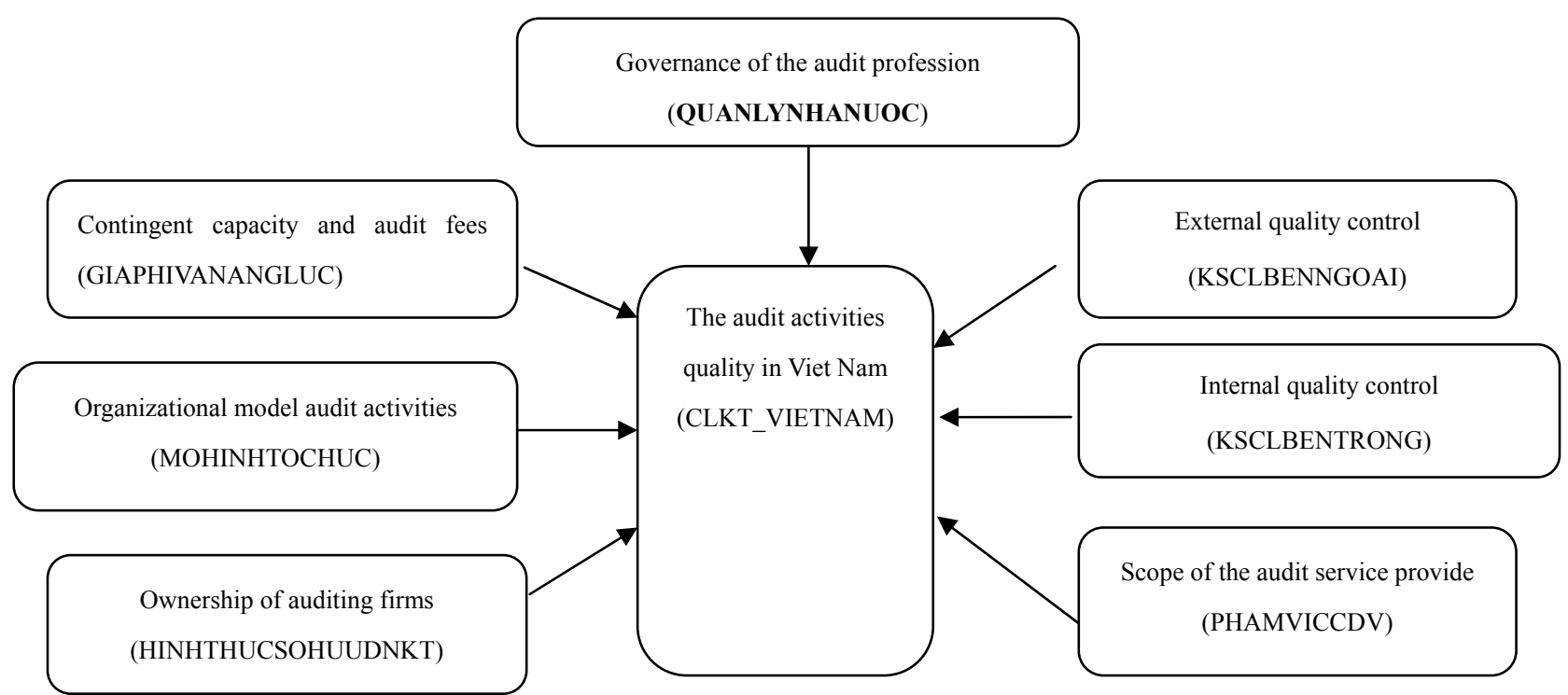

Figure 2. Calibrated model

After renaming the variables, the author has again using Cronbach's Alpha testing to assess the new factors in the model calibration. The results of this test presented in Table 3 shows that the model is considered appropriate. 
Table 3. Testing the calibrated model by Cronbach's Alpha reliability coefficient

\begin{tabular}{lllll}
\hline & $\begin{array}{l}\text { Scale Mean if Item } \\
\text { Deleted }\end{array}$ & $\begin{array}{l}\text { Scale Variance if Item } \\
\text { Deleted }\end{array}$ & $\begin{array}{l}\text { Corrected } \\
\text { Correlation }\end{array}$ & $\begin{array}{c}\text { Item-Total } \\
\text { Cronbach's Alpha if } \\
\text { Item Deleted }\end{array}$ \\
\hline QUANLYNHANUOC & 25.4092 & 12.798 & .622 & .788 \\
GIAPHIVANANGLUC & 25.7182 & 14.553 & .315 & .826 \\
MOHINHTOCHUC & 25.6871 & 13.102 & .564 & .796 \\
KSCLBENNGOAI & 25.4171 & 12.976 & .486 & .807 \\
KSCLBENTRONG & 25.4180 & 12.784 & .522 & .802 \\
HINHTHUCSOHUUDNKT & 25.4197 & 12.170 & .584 & .793 \\
PHAMVICCDV & 25.3482 & 12.756 & .612 & .789 \\
CLKT_VIETNAM & 25.5791 & 12.910 & .621 & .789 \\
\hline
\end{tabular}

After successfully developing the model of factors that affect the audit activities quality in Viet Nam, we processed to assess this model by Multiple Regression (MLR) model to test its appropriateness and to examine the extent to which these factors influence the audit quality. The result of MLR analysis generated by SPSS with "Enter" method is as follows:

Table 4. Result of assessing the calibrated model (model summary ${ }^{\mathrm{b}}$ )

\begin{tabular}{lllll}
\hline Model & $\mathrm{R}$ & R Square & Adjusted R Square & Std. Error of the Estimate \\
\hline 1 & .778 (a) & .606 & .599 & .44754 \\
\hline
\end{tabular}

ANOVA(b)

\begin{tabular}{llllll}
\hline Model & & Sum of Squares & df & Mean Square & F \\
\hline 1 & Regression & 116.664 & 7 & 16.666 & 83.211 \\
& Residual & 75.910 & 379 & .200 & \\
& Total & 192.574 & 386 & & \\
\hline
\end{tabular}

Table 5. Result of MRL with individual regression coefficients in the model

\begin{tabular}{|c|c|c|c|c|c|c|c|c|}
\hline & \multirow[t]{2}{*}{ Model } & \multicolumn{2}{|c|}{$\begin{array}{l}\text { Unstandardized } \\
\text { Coefficients }\end{array}$} & \multicolumn{3}{|c|}{$\begin{array}{l}\text { Standardized } \\
\text { Coefficients }\end{array}$} & \multicolumn{2}{|c|}{ Collinearity Statistics } \\
\hline & & $\mathrm{B}$ & Std. Error & Beta & $\mathrm{t}$ & Sig. & Tolerance & VIF \\
\hline \multirow[t]{8}{*}{1} & (Constant) & -.060 & .174 & & -.342 & .732 & & \\
\hline & QUANLYNHANUOC & -.065 & .043 & -.067 & -1.511 & .132 & .526 & 1.902 \\
\hline & GIAPHIVANANGLUC & .207 & .038 & .192 & 5.442 & .000 & .835 & 1.197 \\
\hline & MOHINHTOCHUC & .628 & .040 & .641 & 15.665 & .000 & .621 & 1.609 \\
\hline & KSCLBENNGOAI & .141 & .033 & .166 & 4.249 & .000 & .684 & 1.461 \\
\hline & KSCLBENTRONG & .079 & .034 & .093 & 2.326 & .021 & .649 & 1.542 \\
\hline & HINHTHUCSOHUUDNKT & -.127 & .037 & -.159 & -3.458 & .001 & .492 & 2.032 \\
\hline & PHAMVICCDV & .168 & .041 & .177 & 4.112 & .000 & .563 & 1.775 \\
\hline
\end{tabular}

a Dependent Variable: CLKT_VIETNAM.

MLR result shows that adjusted $\mathrm{R}^{2}=0.599$, F-test (ANOVA table) expresses the significance level sig. $=0.000$; thus, the regression model is suitable and these factors can explain $59.9 \%$ of the variations of the dependent variable. Considering the regression weights, we can identify the positive correlation between these factors and the audit activities quality (CLKT_VIETNAM), these variables are statistically significant due to do sig. $=.000$ ), there is no sign of multicollinearity, or to be specific, these variables are not inter-correlated.

Also, if based on Table 5, the factor no.1 "Governance of the audit profession" with Sig $=0.132>0.05$ so inappropriate and discarded. Based on Beta coeffiecient, we can arrange the order affects audit quality of these 
factors in turn were: organizational model of business operations audit (factor no. 3), Contingent capacity and audit fees (factor no. 2), scope of service provider (factor no. 7), external quality control (factor no. 4), internal quality control (factor no. 5); Factors no. 6 have negative impact on audit quality.

Thus the model factors affecting audit quality Vietnam remaining six factors with specific equation is:

Quality audit Vietnam $=0.192 *$ Audit fees and capability $+0.641 *$ Model of organization and operation of audit firm $+0166^{*}$ External quality control $+0.093^{*}$ Control internal quality $-0.159^{*}$ ownership of auditing firms + $0.177 *$ Scope of the audit service provide to client

\section{Conclusion}

This is an empirical study on the pattern of factors affecting the quality of audit activities in Vietnam in recent years. Based on the results of research, we came up with the key factors that affect the quality of audit activities were: organizational and operations of audit firm, prices and costs staff capacity of auditing firms, scope of supply of business services to audit clients external quality control, internal quality control; private ownership of auditing firms .

Detection is very important to advice given reasonable solutions thereby improving the quality of audit activities in Vietnam in the coming time.

\section{References}

Arezoo, A. C. (2011). Review of studies on audit quality. International Conference on Humanities, Society and Culture, 20, 312-317. http://dx.doi.org/10.2139/ssrn.2227359

Chia, C. L. (2008). Effects of size on operating result of audit firms with strategic alliances: An empirical study. International Journal of Management, 25, 706-779.

Davidson, R. A., \& Neu. (1993). A note on the association between audit firm size and audit quality. Contemporary accounting research, 2, 479-488. http://dx.doi.org//10.1111/j.1911-3846.1993.tb00893.x

DeAngelo, L. E. (1981a). Auditor independence, 'low balling', and disclosure regulation. Journal of Accounting and Economics, 3, 113-127. http://dx.doi.org/10.1016/0165-4101(81)90009-4

DeAngelo, L. E. (1981b). Auditor size and audit quality. Journal of Accounting and Economics, 3, 183-199. http://dx.doi.org/10.1016/0165-4101(81)90002-1

Financial Reporting Council. (2008). The audit quality framework. Retrieved from http://www.frc.org.uk/Our-Work/Publications/FRC-Board/The-Audit-Quality-Framework-\%281\%29.aspx

Francis, J. R. (2011). A framework for understanding and researching audit quality. Auditing: A Journal of Practice \& Theory, 2, 125-152. http://dx.doi.org/10.2308/ajpt-50006

Lennox, C. (2005). Management ownership and audit firm size. Contemporary Accounting Research, 1, 205-227. http://dx.doi.org/10.1506/K2CG-U6V0-NPTC-EQBK

Leslie, G. C. (1985). International auditing: A comparative survey of professional requirements in Australia, Canada, France West Germany, Japan, the Netherlands, the U.K. and the U.S.A. London: Macmillan.

Linda, E. D. (1981). Auditor size and audit quality. Journal of Accounting and Economics, 3, 183-199. http://dx.doi.org/10.1016/0165-4101(81)90002-1

Ngo, T. C. (2008). Staff in Accounting - auditing in terms of integration: From the practical need to target training. Journal of Auditing, 10, 9-12.

Oxera Consulting Ltd. (2007). Ownership rules of audit firms and their consequences for audit market concentration.

Rita, Y. (2011). Audit firm size, audit fee and audit quality, International conference on business and economic research. Widyatama University Bandung, Indonesia.

Robert, K. W., \& Gropal, V. K. (2012). Audit Quality: Insights from the Academic Literature. http://dx.doi.org/10.2308/ajpt-50350

Timothy, J. L (2011). Auditing and Assurance Services (4th ed.). Mc GrawHill.

Tran, K. L. (2011). Construction quality control mechanism for independent auditing activities in Vietnam. Ph.D Thesis, University of Economics Ho Chi Minh City, Viet Nam.

Tran, T. G. T. (2009). Quality control from external independent audit activities. Finance Publishing. 
Tran, T. K. A. (2008). Vietnam international economic integration in the field of accounting and auditing: Situation and solutions. Ph.D Thesis. Ha Noi foreign trade University, Viet Nam.

Vu, H. D. (2002). Construction system audit standards Vietnam. Ph.D Thesis. University of Economics Ho Chi Minh City, Viet Nam.

Wooten, T. C. (2003). Research about audit quality. CPA Journal, 73, 48-51.

\section{Copyrights}

Copyright for this article is retained by the author(s), with first publication rights granted to the journal.

This is an open-access article distributed under the terms and conditions of the Creative Commons Attribution license (http://creativecommons.org/licenses/by/3.0/). 